\title{
Learning Poetry: Attitudes and Challenges Faced by ESL Students
}

\author{
Taufik Lock Kim Wai \\ School of Education, Universiti Teknologi Malaysia, 81310 UTM Johor Bahru, Johor, Malaysia \\ Hafilah Zainal Abidin* \\ Language Academy, Universiti Teknologi Malaysia, 81310 UTM Johor Bahru, Johor, Malaysia \\ Submitted: 15/08/2019. Revised edition: 26/11/2020. Accepted: 26/11/2020. Published online: 30/11/2020
}

\begin{abstract}
Learning literature, as part of the English Language Syllabus, has been practiced in many countries. In Malaysia, literature is incorporated as a component and an authentic means of learning the language with the hope that students acquire the desired language skills. However, poetry, one of the genres in the component, is the least favourable among students. This paper investigates students' attitude towards learning poetry and the challenges they encountered learning poetry. Data from 120 respondents were collected through questionnaire and interviews. The findings revealed that the selection of texts for poetry in the literature component and teacher's methodology play a role in cultivating students' interest in learning not only the language but also the context, culture, and values as well as inculcating a positive attitude towards learning poetry in second language acquisition.
\end{abstract}

Keywords: Poetry, ESL, students' attitudes, challenges, L2 acquisition

\section{INTRODUCTION}

The incorporation of literature component into the English language Syllabus in 2000 has created a whole new dimension of challenges in English language teaching. Many teachers argue whether the objectives of teaching literature is to fulfil the needs of assessment and evaluation; or to adopt a flexible method which enhances the learners' ability to think for what is beyond the text (Brumfit and Carter, 2000) while making the lesson more meaningful and enjoyable.

The Ministry of Education Malaysia introduced literature as a component into the secondary English Language syllabus in March 2000. The incorporating of the literature element into the English Language syllabus is aimed to promote the better acquisition of the second language learning while inculcating the habit of reading among Malaysian students (Ministry of Education, 2000). Other than that, the incorporation of literature as a component also had hoped to enhance

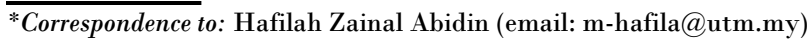


better interest in learning the English Language as a second language (Vethamani, 2007). The inclusion of literature is also aimed to develop one's emotional and spiritual gain, especially in the teaching and learning of poetry.

Literature component in the English Language subject brings a lot of advantages in the teaching and learning of a language. Carter and Long (2003) said that literature provides the opportunity for students to express themselves, contributing aesthetic values and cultivating inner beliefs through the learning of prescribed textbook that consists of poems, short stories, and novels. Likewise, Gurnam (2003) asserts that the acquisition of English could develop greater interest among students to engage other sources of materials in second language learning. The learning of literature as a component in the English Language syllabus is also believed to be able to provide a better and broader perspective of educational function which can trigger critical thinking while increasing emotional awareness that assists in educating a learner as a whole (Lazar, 1991). The incorporation of literature in ELT does make pedagogic interactions more exciting and also opens up opportunities for language acquisition, but also promotes authentic materials that help increases language skills and extends linguistic knowledge (Burhanuddin and Kaharuddin, 2019; Rabb Khan and Alasmari, 2018)

Poetry, as one of the main genres of the literature component, provides a rich, varied repertoire and source of enjoyment for learners (Brumfit and Carter, 2000). Although prescribing poems may benefit High English Proficiency learners in acquiring the language efficiently, not all students have a good command of the language. The lack of proficiency in the English Language discourages students from exploring more reading materials, especially when the texts provided are beyond their language competency (Siti Norliana, 2008). Most second-language learners who possess intermediate to limited language proficiency may encounter difficulties in comprehending the prescribed poems, resulting in negative attitudes towards the learning of poetry. Hence, students' attitude and perception play a significant role in determining the acquisition of learning skills in a classroom (Brown, 2000).

There has been research conducted on second language acquisition (SLA), attitudes and background knowledge of English. Still, there is little research on students' attitude in learning poetry as a component of the English Language syllabus and the challenges that students encounter to gain an in-depth understanding of poetry. In fact, there is a scarcity of research conducted on the attitude and perception of learners towards the learning of poetry in the Malaysia context. Therefore, this paper will discuss the findings of a study which investigated students' attitude and perception towards learning poetry in selected suburban schools in the district Johor Bahru.

\section{BACKGROUND OF STUDY}

The introduction of literature as an elective subject for form four and five in 1998 saw a paradigm shift for English learning in the Malaysian education system. In the year 2000, literature was incorporated as an evaluated component in the English as a Second Language Syllabus; preliminary started with the first implemented prescribed text which consists of six poems, five short stories, and a novel. Conclusively, the learning of literature as a component aimed to accomplish and fulfil the 
main objectives of the National Education Philosophy (Falsafah Pendidikan Negara), which is to mould each learner as an intellectually, spiritually, emotionally and physically enriched and developed individual.

The elements of literary learning are also found in the reading of texts for primary four, five and six as part of an enrichment programme, in preparation for more challenging new literary text such as Journey to the Centre of the Earth for the new form one prescribed text. As for the upper secondary, critical review of a prescribed novel is being tested with the reward of 20 marks and the structured assessment of poetry signifying the high allocation of scoring for learners who can perform well in the literature component. Generally, until very recently, the learning of English language remains crucial especially when the Ministry of Education announced a compulsory for learners to pass the English language paper in the Sijil Pelajaran Malaysia - a public examination, in 2009. A credit in the English Language subject enables graduates to gain a ticket which allows them to apply to enter public institutes of higher learning, varsities and even for career development.

The inclusion of poetry in the Malaysian English language curriculum for secondary schools provides the platform for the growth of literature in Malaysian schools thus preparing students for higher-level literary understanding and enabling them to proceed to higher levels of literary appreciation. Gaining literary skills will also assist the students in achieving better results in the English Language prerequisite examination such as the Malaysian University English Test (MUET). The general aims of teaching literature as a component outlined by the Curriculum Development Centre (2000) are as below:

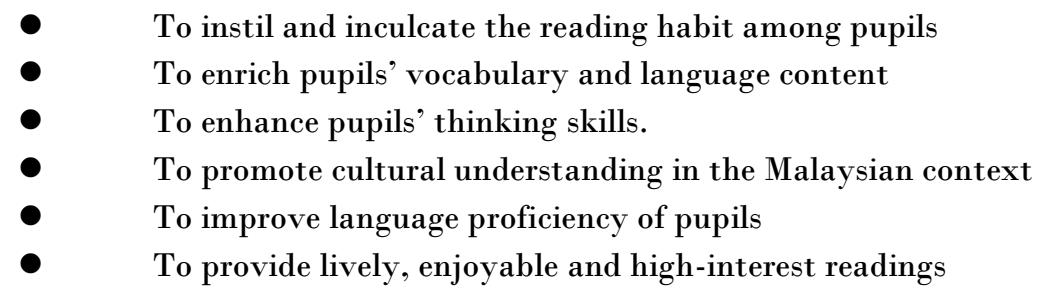

Shireena and Vethamani (2010) highlight that literature holds the significance of inculcating aesthetic appreciation. As clearly stated in the guideline of learning outcomes by the Ministry of Education, learners should be able to discuss the shortcoming of the characters of a short story or novel, plot, setting, values and other literary elements in the text where learners will gradually learn methods to appreciate a literary text. Many previous studies (e.g. Vethamani, 2004 and Shaukat and Khan, 2020) have suggested that incorporating literature in English as a component should assist learners to improve their language skills, especially reading while providing adequate education needs and pleasure when exploring literary text.

Poetry, as one literature components, offers a number of instructional advantages for language learners. Firstly, poetry is "produced" in a minimal number of words, enabling learners to read repeatedly in a limited time constraint while gaining the maximum input, especially learning a new stream of vocabulary (Cullinan et al., 1995). It is, in fact, the length of the text is motivating the learners to explore the text more meaningfully comparing to prose. 
In addition, due to its brevity, poetry serves as an expandable in-depth analysis of a text, thus promoting learner's critical thinking skills. In fact, most poems which have the elements of rhyme, rhythm and repetition enhance learners to learn better, memorize effectively while making reading more enjoyable and less structured to 'conventional texts' (Gill, 1996).

Another strength of learning poetry is reading aloud (Mc Rae, 1991). The meaning of a poem is usually conveyed when it is read and listened to. These classroom activities enable language learners to acquire correct word pronunciation and enunciation, thus promoting learners' fluency and confidence to explore the target language meaningfully. Poetry also promotes the concept of "narrow reading' where learners could explore a poem based on their thematic preferences which may result in rich vocabulary acquisition. Besides thematic findings, poetry also opens a dimension for learners to explore and understand the universal shortcomings of human beings and situations more relatively significant to them (Ur, 2012). Hence, a study that examines learners' perceptions and attitudes toward learning poetry can provide important insights into the teaching and learning of literature in schools.

\section{REVIEW OF RELATED LITERATURE}

In the past two decades, it is evident that the incorporation of literature component has gained interest amongst curriculum planners, syllabus and material designers as well as practitioners in the areas of English as a Second Language and English as a Foreign Language worldwide (Lazar, 1996; Carroli, 2002). The teaching of literature with the small ' $\mathrm{l}$ ' has attracted the incorporation of literature into language curricula such as in the United States (Langer, 1995), United Kingdom (McRae, 1991), Australia (Carolli, 2002), Turkey (Erkaya, 2005), Taiwan (Carlisle, 2000), Japan (Norris, 1995) and Singapore. This phenomenon is due to its alternative ability to drive learners to learn the target language meaningfully while generating critical thinking and interest among the learners. In Malaysia, literature as a component of the English Language subject was implemented in all government schools in 2000. The introduction of the literature component aims to inculcate the elements of literature into language teaching and to cultivate the habit of reading materials and sources in the English Language. In 2003, it became a tested component for the two national examinations at the secondary levels in Malaysia which are the Middle School Assessment (PMR) and the Malaysian Certificate of Education (SPM) which is taken by high school students in Form 3 and Form 5 respectively. Following the incorporation of the teaching of literature component in secondary education, in 2005, the Contemporary Children's Literature (CCL) Program was introduced to students in Year 4 with the primary aim of improving the students' language through reading a simple fiction and preparing them for the literature component in secondary schools (Vethamani, 2007).

In line with Malaysia's Educational Philosophy, the incorporation of literature component has also been viewed as a basis to provide a concrete foundation to develop an understanding of other societies, cultures, values and traditions that will assist the learners in their emotional and spiritual growth as 
being stated in Malaysia's Educational Philosophy. Mc Rae (1991) suggests that learners often read a literary text to enjoy a good story and thus building the desire to explore reading skills despite linguistic hindrances that motivate them to explore more. In fact, for poetry, one of the dramatically effective methods of teaching poetry is reading aloud, claiming dynamic results (Tomlinson, 1986). Ur (1996) also asserts that learning poetry encourages developing various reading skills. However, a study by Tina Abdullah et al. (2007) found that the previously prescribed poems for the upper secondary school syllabus ( Form 4 and 5) namely "Sonnet 18" (William Shakespeare), "The Road Not Taken" (Robert Frost), "There's Been Death in the Opposite House" ( Emily Dickinson ), "Monsoon History" ( Shirley Lim), "Si Tenggang's Homecoming" (Muhamad Haji Salleh), and "If" (Rudyard Kipling) were not all preferred by the students as some were too challenging for them to comprehend. It could be the reason for the lack of interest in reading the prescribed literature text.

Additionally, Gurnam (2003) also found that more than sixty percent of the students considered the prescribed texts as tedious. Studies have also indicated that the exercises and materials based on literature texts were prepared and chosen for the students but the students themselves, were not given much attention and opportunity to explore beyond what they were capable of, especially students with a higher proficiency of the target language (Vethamani, 2003). In another study, the teaching of poetry was performed by a fully translating it into Malay Language - a last-ditch effort by teachers who considered it the only way to ensure that students were able to answer the examination questions (Dulip, 2006). This indicates that the need to pass an examination has superseded the essence of the inclusion of poems in the English Language Program, that is, to "read and understand poetry for enjoyment." On the one hand, Tina Abdullah et al. (2007) also discovered that students who had low proficiency levels were not motivated to learn the language, multiplying the challenges of a learner in identifying literary elements, especially in poetry. In the ESL framework, this notion of reading habit does not apply well in the context in which other native languages seem to play a dominant role in the daily usage of mother tongue or Ll language, which appears to be the main challenge when encouraging learners to read L2 texts.

\section{METHODOLOGY}

The primary concern of this study was to examine students' attitude towards learning poetry and the challenges they encountered in learning poetry. The participants of this study comprised one hundred twenty respondents from a selected suburban school. The 120 Form Four students were randomly chosen for the study. The main instrument used to collect data in this study was a questionnaire. Table 1.1 outlines the items contained in the questionnaire. 
Table 1.1 Items in the questionnaire

\begin{tabular}{|c|c|}
\hline No. & Item \\
\hline 1 & I like reading this poem. \\
\hline 2 & $\begin{array}{c}\text { The language used in this poem is } \\
\text { difficult to understand. }\end{array}$ \\
\hline 6 & $\begin{array}{c}\text { I am able to relate this poem to my } \\
\text { personal experience. }\end{array}$ \\
\hline 13 & $\begin{array}{c}\text { I am able to answer examination } \\
\text { questions related to the poem } \\
\text { without any difficulty. }\end{array}$ \\
\hline 5 & $\begin{array}{c}\text { I do not understand reading this } \\
\text { poem. (Im)* }\end{array}$ \\
\hline $8 *$ & $\begin{array}{c}\text { I can understand the theme and } \\
\text { values of the poem without any } \\
\text { difficulty. (Im)* }\end{array}$ \\
\hline 9 & $\begin{array}{c}\text { I can identify the use of simile in the } \\
\text { poem easily. (Ipd)* }\end{array}$ \\
\hline 10 & $\begin{array}{c}\text { I can identify the use of personifi- } \\
\text { cation in the poem easily. (Ipd)* }\end{array}$ \\
\hline
\end{tabular}

Respondents choose options from a 6-point Likert scale that best reflect their attitudes towards learning poetry (items 1, 2,6 and 13) and the perceived challenges they face (items 5, 8, 9 and 10). The findings were later analysed according to the mean score of four levels of highly positive, positive, negative and highly negative level to the learners' attitude towards each statement. In addition, an interview was also conducted with ten randomly selected students to gain better insights regarding the issue. The two poems selected for this study were poems that students learned in the Form Four Literature component: "In the Midst of Hardship" by Latif Mohideen, and "He Had Such Quiet Eyes" by Bibsy Soeharjo.

\section{RESULTS}

The levels and interpretation of total scores are shown in Table 1.2. 
Table 1.2 Mean scores, total scores and attitude level

\begin{tabular}{lll}
\hline Mean Score & Total Score & Attitude Level \\
\hline $4.76-6.00$ & $335-420$ & Highly Positive \\
$3.51-4.75$ & $247-334$ & Positive \\
$2.26-3.50$ & $158-246$ & Negative \\
$1.00-2.25$ & $70-157$ & Highly Negative \\
\hline
\end{tabular}

As can be seen from Table 1.2, the total scores from the 6-point Likert scale were analysed to determine the attitude level. The findings were summarized in the range of mean score as four levels of highly positive, positive, negative and highly negative level to the learners' attitude towards each statement.

\section{Students' Perception in Learning the Prescribed Poems}

Table 1.3 shows the students' perception in learning the two prescribed poems for Form Four students in the literature component textbook.

Table 1.3 Students' perception in learning the prescribed poems

\begin{tabular}{|c|c|c|c|c|c|}
\hline \multirow{3}{*}{ No. } & \multirow{3}{*}{ Item } & \multicolumn{4}{|c|}{ Title of the Poem } \\
\hline & & \multicolumn{2}{|c|}{$\begin{array}{l}\text { In the Midst of } \\
\text { Hardship }\end{array}$} & \multicolumn{2}{|c|}{$\begin{array}{l}\text { He Had Such Quiet } \\
\text { Eyes }\end{array}$} \\
\hline & & $\begin{array}{l}\text { Mean Score/ } \\
\text { Percentage in } \\
\text { Agreement }\end{array}$ & $\begin{array}{l}\text { Attitude } \\
\text { Level }\end{array}$ & $\begin{array}{l}\text { Mean Scorel } \\
\text { Percentage in } \\
\text { Agreement }\end{array}$ & $\begin{array}{l}\text { Attitude } \\
\text { Level }\end{array}$ \\
\hline 1 & I like reading this poem. & $\begin{array}{l}4.46 \\
(86.7)\end{array}$ & Positive & $\begin{array}{l}4.73 \\
(89.2)\end{array}$ & Positive \\
\hline 2 & $\begin{array}{l}\text { The language used in this poem is } \\
\text { difficult to understand. }\end{array}$ & $\begin{array}{l}3.53 \\
(54.2)\end{array}$ & Positive & $\begin{array}{l}3.59 \\
(54.2)\end{array}$ & Positive \\
\hline 6 & $\begin{array}{l}\text { I am able to relate this poem to my } \\
\text { personal experience. }\end{array}$ & $\begin{array}{l}3.58 \\
(54.2)\end{array}$ & Positive & $\begin{array}{l}3.68 \\
(55.0)\end{array}$ & Positive \\
\hline 13 & $\begin{array}{l}\text { I am able to answer examination } \\
\text { questions related to the poem } \\
\text { without any difficulty. }\end{array}$ & $\begin{array}{l}3.83 \\
(63.4)\end{array}$ & Positive & $\begin{array}{l}3.97 \\
(68.4)\end{array}$ & Positive \\
\hline \multicolumn{2}{|c|}{ Total Average Mean Score } & 3.85 & Positive & 3.99 & Positive \\
\hline
\end{tabular}

Overall, the results in Table 1.3 reveal that the respondents were in favour of learning the two prescribed poems. The average mean score of 3.99 suggesting that respondents were slightly more interested in learning He Had Such Quiet Eyes as compared to the average mean score of 3.85 for the 
poem In the Midst of Hardship. These results may suggest that the respondents were more favourable on the theme of love to the theme of survival. However, more than half of the respondents $(54 \%)$ believed that the language used for both poems was challenging for them (item 2) as suggested by the lower mean score of 3.53 and 3.59 for both poems respectively. Surprisingly, the average scores of 3.83 and 3.97 for item 13 shows that more than half of the respondents believed that they could answer examination questions related to the poem without any difficulty despite limitation in the language.

Although more than $86 \%$ of the respondents liked reading both poems (item 1), only half of the respondents $(54.2 \%$ and $55 \%)$ agreed that they could relate both poems to their personal experience (item 6). Item 6 also had a lower mean score of 3.58 and 3.68 for both poems respectively. The results could suggest that the respondents need teachers to guide and facilitate them in relating the lesson to their real-life experience.

\section{Challenges Students Encountered in Learning the Prescribed Poems}

Table 1.4 shows the possible areas of challenges where the students might have encountered in learning the two prescribed poems for Form Four. The poems are In the Midst of Hardship by Latif Mohideen, and He Had Such Quiet Eyes by Bibsy Soeharjo.

Table 1.4 Areas of challenges in learning the form 4 prescribed poems

\begin{tabular}{|l|l|l|}
\hline \multirow{2}{*}{ Areas of Challenges } & Title of the Poem \\
\cline { 2 - 3 } & In the Midst of Hardship & He Had Such Quiet Eyes \\
\hline $\begin{array}{l}\text { Interpreting } \\
\text { Meaning/Messages }\end{array}$ & 3.37 & 3.33 \\
\hline Identifying Poetry Devices & 3.43 & 3.46 \\
\hline $\begin{array}{l}\text { Total Average Mean } \\
\text { Score/Attitude Level }\end{array}$ & $\begin{array}{l}3.40 / \\
\text { Negative Attitude }\end{array}$ & $\begin{array}{l}\text { Negative Attitude } \\
\text { Negat }\end{array}$ \\
\hline
\end{tabular}

Based on the results of the total average mean score of 3.40 and 3.39 for both poems respectively, the students had experienced challenges almost equally in both of the areas of difficulties; that are interpreting meaning and messages of a poem and identifying poetry devices in a poem. Further explanations for specific findings of students' challenges in learning the prescribed poems are presented in the following Table 1.5. 
Table 1.5 Challenges faced by students in learning the form 4 prescribed poems

\begin{tabular}{|c|c|c|c|c|c|}
\hline \multirow[b]{3}{*}{ No. } & \multirow[b]{3}{*}{ Item } & \multicolumn{4}{|l|}{ Title of the Poem } \\
\hline & & \multicolumn{2}{|c|}{ In the Midst of Hardship } & \multicolumn{2}{|c|}{ He Had Such Quiet Eyes } \\
\hline & & $\begin{array}{l}\text { Mean Score/ } \\
\text { Percentage (\%) } \\
\text { In Agreement }\end{array}$ & $\begin{array}{l}\text { Attitude } \\
\text { Level }\end{array}$ & $\begin{array}{l}\text { Mean Score/ } \\
\text { Percentage (\%) } \\
\text { In Agreement }\end{array}$ & Attitude Level \\
\hline $\begin{array}{l}5 \\
* *\end{array}$ & $\begin{array}{l}\text { I do not understand } \\
\text { reading this poem. } \\
(\mathrm{Im})^{*}\end{array}$ & $\begin{array}{l}4.29 \\
(24.2)\end{array}$ & Negative & $\begin{array}{l}4.08 \\
(29.2)\end{array}$ & Negative \\
\hline 8 & $\begin{array}{l}\text { I can understand the } \\
\text { theme and values of } \\
\text { the poem without any } \\
\text { difficulty. (Im)* }\end{array}$ & $\begin{array}{l}3.68 \\
(59.2)\end{array}$ & Positive & $\begin{array}{l}3.68 \\
(57.5)\end{array}$ & Positive \\
\hline 9 & $\begin{array}{l}\text { I can identify the use } \\
\text { of simile in the poem } \\
\text { easily. (Ipd)* }\end{array}$ & $\begin{array}{l}3.59 \\
(56.6)\end{array}$ & Positive & $\begin{array}{l}3.61 \\
(60.0)\end{array}$ & Positive \\
\hline 10 & $\begin{array}{l}\text { I can identify the use } \\
\text { of personifi-cation in } \\
\text { the poem easily. } \\
(\mathrm{Ipd})^{*}\end{array}$ & $\begin{array}{l}3.38 \\
(47.5)\end{array}$ & Negative & $\begin{array}{l}3.43 \\
(51.6)\end{array}$ & Negative \\
\hline
\end{tabular}

Table 1.5 shows the areas in which students faced challenges in learning the specific poem. An average of $67 \%$ of the students had difficulties in interpreting the figurative meaning for both of the poems. Similarly, respondents reported facing challenges in learning poetry in general, with $70.8 \%$ of the respondents agreed that they faced difficulties in interpreting messages in a poem. These findings are also supported by the mean score of 3.85 and 3.75 for both poems, respectively.

Most of the students involved in this study experienced difficulties in identifying literary devices in poetry which they found to be far too challenging. The average mean scores from 3.29 to 3.61 suggest that $58 \%$ of the respondents had difficulties in identifying the use of personification, metaphorical language and symbolism in both of the poems prescribed in the form four literature component textbook. However, literary devices like simile, which usually has word or phrases such as like and as was less challenging for the students as nearly $60 \%$ of them agreed that they were able to identify the use of simile in both poems without difficulty.

This study also found that about two-thirds of the students were able to comprehend both of the poems without much difficulty as more than $72 \%$ of the respondents claimed that they could understand the poem. This is indicated by the high mean score of 4.29 and 4.08 for both poems, respectively. However, many were not able to identify the theme and values. The lower mean score of 3.68 for both poems indicates that the learners have yet to acquire skills to identify literary elements 
in poetry. The results suggest that teachers need to be creative in exchanging ideas with students and be able to prompt meaningful discussion during poetry lessons.

\section{DISCUSSIONS}

The study found that appropriate text selection would be beneficial for students to have pleasure and enjoyment while exploring the text meaningfully. Meaningful lessons through poetry could instil a positive attitude in language learning as this usually allows students' personal experience to be channelled into the lesson (Mc Rae, 1991). Literature helps students to acquire self-confidence to express, respond and polish their thinking skills while using the target language (Collie and Slater, 2001). This study also gives an outlook of students gaining better confidence in answering and responding to their examinations through learning poetry as reflected in the students' favourable attitude toward the two prescribed poems. In addition, students have better opportunities to relate poems to their personal experience. Although findings revealed that the students had difficulty with the language used in the poems, the level of positive attitude towards both the poems outweighed linguistic hindrance through meaningful and enjoyable activities (Harmer, 2016). Learning poetry provides the opportunity to address human which transcend cultural and generational gaps. However, the findings of this study revealed that the students were less able to relate to the poem "In the Midst of Hardship" as compared to "He Had Such Quiet Eyes". This may be due to the former poem, which is set in the 1950's where hardship and flood dominated the lives of the majority of villagers in remote areas. The students were, however, exposed to living situations and the hardships faced in the past, bridging the generational gap through learning poetry.

The findings also revealed that the students were more interested in poems which they can relate to. The poem "He Had Such Quiet Eyes" by Bibsy Soeharjo highlighted the issues of love and teenage life sparked greater interest among the students despite the difficulties in identifying poetic devices in the poem. Here, it indicates that texts with love and social values themes assist and motivate learners to explore literary works on their own. This finding is supported by the personal growth model which is basically the most feasible way of teaching literature in first and even second language contexts (Carter and Long, 1991). Candlin (2010) suggest that learners are supposed to be able to relate their motivation level to their cognitive development where learners tend to read and learn more once they have achieved what is desired based on the text prescribed. Most participants agreed that they have yet to acquire the skill and ability to comprehend the elements in poetry, although one of the participants was able to comprehend and communicate well in the target language. Hence, it shows that learning poetry in Form Four should be reconsidered under the guidelines of appropriate themes, the level of the language in the poem, and values to be instilled.

Meanwhile, the students also revealed that they had learned essential values of hardship and survival from the poem In the Midst of Hardship. As the poem was set in the local context, the students admitted that learning the poem was less challenging as the students felt that they were not 'alienated' from the text. This discovery supports the notion that using a familiar context for 
literature in the English Language teaching would enable the learners to gain values, history and cultures of the target language (Carter and Long, 1991).

The two main challenges that students in suburban area may encounter in learning poetry are language proficiency and pedagogical approach. About $60 \%$ of the participants admitted that their language is not 'good' and this could be a significant reason why they were not able to interpret texts effectively. As the use of literature is to promote language learning (Mc Rae, 1991), the learners were actually 'forced' to read the text while most of them were struggling to identify and interpret meanings; regardless whether it is denotative or connotative. This deficit could turn out to be another challenge for teachers as teachers need to accomplish the syllabus requirement in the allocated time and schedule. The students may require more time to learn a poem than what the teacher previously expected. This will result in spoon-feeding practice at the end of the lesson as the teacher needs to compensate for the time loss during poetry lessons. Hence, students' language ability might be the most critical factor in learning poetry. The learning of poetry requires a certain level of language proficiency, cognitive ability and maturity in order to comprehend the text well (Najwa, 2010). In fact, study by Nambiar et al. (2020) has pointed out the role of cultural awareness in facilitating understanding of a reading text. This situation may be frustrating for teachers as the curriculum is still very much exam-oriented with a heavy focus on assessment and evaluation.

Due to the situation, carrying out creative and meaningful activities stand a limited chance in a poetry lesson. Again, this may develop into a vicious cycle in the methodology applied by the teachers. Indeed, students' language proficiency could be considered as the main problem in second language learning. As for students with limited language proficiency, learning poetry may indirectly add to their confusion of the language as highlighted in the article Literature in ESL Classroom: Roses or Thorns (Sarceni, 2003).

Based on the findings of the challenges that students encounter in learning poetry and the prescribed poems, the concept of comprehensible input in language learning plays a dominant role in students' attitude towards learning the poems. Majority of the respondents claimed that they faced difficulty in interpreting the message or meaning of the poems and also in identifying poetry elements such as mentioned in the findings. Here, this could be perceived that the linguistic level of the comprehensible input might have exceeded beyond the students' $i+1$ current linguistic competence. This result is similar to the study by Tina Abdullah et al. (2007) which discovered that most learners have negative attitudes towards the learning of poetry regardless of their proficiency level and the materials prescribed. However, in this study, it is evident that the majority of the respondents did not highlight language difficulty, but it was their cognitive inability to perform text analysis beyond the encapsulated version (Rush, 2005). This finding is supported by the following responses gathered during the interview:

'...sometimes in a poem, it not easy to understand the meaning. The more difficult thing is to draw the main theme of the poem. At times we feel like giving up when (the) teacher asks for the theme of the poem where we usually got it wrong.' (Interviewee STI)

'...language also sometimes very difficult. What the poem writes and what they mean is totally different one.' (Interviewee BSC 34) 
'...the most difficult thing is the message. Usually, we don't understand how to think for (about) (the) message because what we read and understand is a little bit different from what the teacher explains.' (Interviewee CSC 22)

'... I hate to think for the language thing in the poems. Symbol la, metaphor la, imageries la, don't what is that also...' (Interviewee EA 14)

Here, it indicates that students need to be guided and facilitated meticulously in exploring a text. Teachers must motivate students to attempt self-discovery of a text where this is aimed to provide lively, enjoyable and high-interest readings as stated in the goals of teaching literature by the Curriculum Development Council.

Siti Norliana (2008) argues that students' limited proficiency of English Language discourages them from exploring the texts prescribed. It is also found that texts which are remote to the students could hinder the students' learning process regarding the material used. The implication is that English teachers should ensure that the students feel motivated while providing a conducive learning environment in the poetry class. Teachers have an important role to play in a poetry lesson since the students in the classroom are usually dependent on the teacher to assist them in fulfilling their learning needs. The responses during the interview support this notion:

'...teacher is very important one. Sometimes when the teacher teach(es) very fast, we don't understand. But when slow, we can understand...' (Interviewee CSC 18)

'... I like the lesson when the teacher uses songs and slides to teach us...it is very much easier for us to understand, especially when we are to think about what's should we do and what we must not do as a human being...' (Interviewee BSC 6)

'...I don't like my teacher...My teacher always give(s) us exercises only. Seldom tell us stories about something in the poem...very boring...' (Interviewee ST 9)

'...the poems are ok la...not so difficult. Because our teacher usually use(s) us as (an) example in the class one...like that we can understand better...'(Interviewee EA 27)

\section{CONCLUSION}

Overall, the study revealed that the Form Four students from the selected suburban school in Johor Bahru had a positive attitude in learning poetry. It also provides insight for the teachers or the researcher to understand how students in a suburban school perceive and learn poetry. The findings indicated that the majority of the students had an interest in learning poetry and portrayed a positive attitude towards the poems prescribed despite the difference in cultural context and settings in the 
poems. Although more than $80 \%$ of the students showed favourable attitude towards the prescribed poetry, more than half of the students agreed that they struggled to interpret the message, meaning as well as to identify the poetic devices. Hence, identifying and understanding poetic devices such as figurative language, metaphor, simile, and personification are the biggest challenges faced by learners when making literary interpretations. Despite the short repetitive lines of a poem, the ambiguous meaning of phrases or words in the poems would become too taxing (Dulip, 2006) especially for students who are less proficient in the language. This experience could result in frustration and demotivates students to explore poetry.

Furthermore, it appears that the positive attitude of the students towards learning poetry can be hampered by a negative learning environment that could be caused by the texts prescribed or even the teacher. Unfamiliar vocabulary, grammar and sentence structure may hamper students' understanding of the text leading to misinterpretation of text, thus unable to achieve the objectives of the lesson (Fecteau, 1999). Hence, it is reasonable to conclude that despite the challenges encountered by the students, teachers carry a challenging task in guiding the students to develop their ability to interpret poems and literary works provided in the prescribed text. Teachers have a significant role in facilitating and guiding the students to achieve the objectives of a lesson. Even though students are expected to perform well during examinations, teachers must also uphold their duty not only to impart knowledge but also to shape students' attitude towards life-long education and education as a whole. Hence, the teaching of poetry with the best selection of poems is hoped to contribute awareness among the students. It is also aimed that through learning poetry, moral values can be instilled among students. In other words, future educators must be made aware of the importance of pedagogical approaches, the influence of the prescribed texts and also the learners' proficiency level on the teaching of poetry. A good teacher would be able to inspire his or her students regardless of their background and language proficiency.

\section{REFERENCES}

Arafah, B., \& ., K. 2019. The Idol: A Model for Incorporating Literature in Elt. KnE Social Sciences. 3(19): 43-59. https://doi.org/10.18502/kss.v3i19.4829.

Brumfit, C. J. and Carter, R. A. 2000. Literature and Language Teaching. Oxford: Oxford University Press.

Candlin, C. 2010. English Language Teaching in Its Social Context: A Reader. London: Routledge.

Carlisle, A. 2000. Reading Logs: An Application of Reader-response Theory in EFL. ELT Journal. $54(1)$.

Carroli, P. 2002 Perceptions of Literature: A Comparison of Students' and Educators' View. Australian National University: Griffith University. 113-128.

Carter, R., and Long, M. N. 1991. Teaching Literature. Essex, England: Longman.

Collie, J. and Slater, S. 2001. Literature in the Language Classroom: A Resource Books of Ideas and Activities. Cambridge: Cambridge University Press. 
Cullinan, B., Scala, M. and Schroder, V. 1995. Three Voices: An Invitation to Poetry Across the Curriculum. ME: Sternhouse Publishers.

Dulip, S. 2006. Assessment of the Literature Component in the Form 4 Malaysian English Language Language Syllabus in a School. Journal Akademik IPTAR.

Erkaya, O. R. 2005. TV Commercials as Authentic Tools to Teach Communication, Culture and Critical Thinking. MexTESOL Journal. 29(1).

Fecteau, M. L. 1999. First and Second Language Reading Comprehension of Literary Texts. The Modern Language Journal. 83(4).

Gill, S. 1996. Shared Book Experience with Poetry: The State of Reading. Journal of the Texas State Reading Association. 3(1).

Gurnam Kaur Sidhu. 2003. Literature in the Language Classroom: Seeing Through the Eyes of Learners. In G. Subramaniam (Ed.). and M.E. Vethamani (General Editor). Teaching of Literature in ESL/EFL Context. Petaling Jaya: Sasbadi-MELTA ELT Series.

Harmer, J. 2016. The Practice of English Language Teaching. 5th ed. Cambridge: Longman.

Lazar, G. 1999. Exploring Literary Text with the Language Learner. TESOL Quarterly. 30(4).

McRae, J. 1991. Literature with a Small 'l'. London: McMillan Publishers Limited.

Ministry of Education 2000. Literature in English for Upper Secondary Schools: Selected Poems and Short Stories, Form 4. Dewan Bahasa dan Pustaka.

M. K. Nambiar, R., Noraini Ibrahim, Hashim, R. S., Mohammad Yasin, R., Azman, H., Mohd. Yusof, N., Ramli, R. and Mustaffa, R. 2020. Impact of Local Culture-Based Reading Materials on Students' Skill Development and Confidence in English. Universal Journal of Educational Research. 8(2): 445-453.

Najwa, N. 2001. The Use of Poetry in TEFL: Literature in the New Lebanese Curriculum. CAUCE. 24.

Norris, R. W. 1995. Getting Students More Personally Involved in Their Reading and Literature Classes: A Case Study. Fukuoka Women's Junior College Studies. 49: 35-48.

Rabb Khan, M., \& Alasmari, A. M. 2018. Literary Texts in the EFL Classrooms: Applications, Benefits and Approaches. International Journal of Applied Linguistics \& English Literature. 7(5), 168-179.

Rush, P. 2005. Behind the Lines: Using Poetry in the Language Classroom.

Sarceni, M. 2003. Literature in the EFL Classroom: Roses of Thorns? In Subramaniam, G. and Vethamani M. E. (Eds). Teaching Literature in ESL/EFL Context. Petaling Jaya: Sasbadi Sdn. Bhd.

Shaukat Ali and Khan, T.W. 2020. The Impact of Poetry on Developing Grammatical Competence of English as Second Language Learners. (2020). Hamdard Islamicus. 43(1): 668-679.

Shireena, B. and Vethamani, M. E. 2010. Approaches Employed by Teachers in Teaching Literature in a Less Proficient Students in Form 1 and Form 2. 3(4).

Siti Norliana. 2008. Learners' Background and Their Attitudes Towards Studying Literature: Vol 4. Malaysia Journal of ELT Research MELTA. Universiti Teknologi Mara: Malaysia 
Tina, A., Mohammad, H. Z., Fauziah, I., Wan Fara Adlina, W.M. and Marzilah, A. A. 2007. A New Teaching Model to Teach Literature for the TESL Pre-Training Service Programme in Universiti Teknologi Malaysia, UTM. Eprints.

Tomlinson, B. 1986. Using Poetry with Mixed Ability Language Classes. ELT Journal. 40(1).

Ur, Penny. 2012. A Course in Language Teaching, Practice and Theory. Cambridge: Cambridge University Press.

Vethamani, M. E. 1996. Common Ground: Incorporating New Literatures in English in Language and Literature Teaching. In Carter, R. and McRae, J. (Eds.). Language, Literature and the Learner: Creative Classroom Practice. Addison Wesley Longman: New York.

Vethamani, M. E. 2004. New Englishes New Literature in English: Challenges for ELT Practitioners.

In Ganakumaran, S. (Ed.). Teaching Literature in ESL and EFL Context. Petaling Jaya: Sasbadi Sdn. Bhd.

Vethamani, M. E. 2007. Reading Literary Texts. The English Teacher. XXXVI: 20-33. 